\title{
ECTOPIC CHORIOCARCINOMA IN A PRETEEN IN OGBOMOSO, SOUTH-WEST NIGERIA. A CASE REPORT
}

\author{
Ogunlaja A. Olumuyiwa, ${ }^{1}$ Ano-Edward H. Gbemi, ${ }^{2}$ Fehintola O. Akintunde, ${ }^{1}$ \\ Alao A. Michael, ${ }^{3}$ Awotunde T. Olufemi, ${ }^{4}$ Ogunlaja P. Idowu, ${ }^{5}$ Aaron Olurotimi, ${ }^{6}$ Idowu Ajibola, \\ Fehintola O. Funmito, ${ }^{7}$ Bojuwoye O. Matthew, ${ }^{8}$ Oladeji A. Sunday, ${ }^{4}$ Lasisi E. Matthew ${ }^{2}$ \\ ${ }^{1}$ Department of Obstetrics and Gynecology, Bowen University Teaching Hospital, Ogbomoso, Nigeria \\ ${ }^{2}$ Department of Anatomic Pathology, Bowen University Teaching Hospital, Ogbomoso, Nigeria \\ ${ }^{3}$ Department of Pediatrics, Bowen University Teaching Hospital, Ogbomoso, Nigeria \\ ${ }^{4}$ Department of Family Medicine, Bowen University Teaching Hospital, Ogbomoso, Nigeria \\ ${ }^{5}$ Department of Obstetrics and Gynecology, General Hospital, Ilorin, Nigeria \\ ${ }^{6}$ Department of Anesthesia, Bowen University Teaching Hospital, Ogbomoso, Nigeria \\ ${ }^{7}$ Department of Community Medicine,Bowen University Teaching Hospital, Ogbomoso, Nigeria \\ ${ }^{8}$ Department of Internal Medicine, University of Ilorin Teaching Hospital, Ilorin, Nigeria
}

Prihvaćen /Accepted 23. 11. 2016. god.

Abstract: Ectopic Choriocarcinoma is an extremely rare occurrence. The case of ectopic choriocarcinoma discussed here involved a 12 year old girl who presented with lower abdominal pain and dizziness following a short period of amenorrhea after attaining menarche. A provisional diagnosis of ruptured ectopic gestation was made based on the clinical evaluation and patient had emergency laparotomy. Histopathology report revealed a choriocarcinoma of the ovary. Patient defaulted on subsequent follow up care. This case is presented as an eye opener on the need to also focus on the reproductive health challenges, early sex education in preteen and rare occurrence of the disease amongst the Pre-teenage groups. It is also important to deal with the possibility of a non gestational choriocarcinoma of the ovary which has a worse prognosis.

Keywords: Ectopic Choriocarcinoma, Preteenage, ruptured ectopic gestation, departed against medical advice.

\section{INTRODUCTION}

Trophoblastic tumours like choriocarcinoma rarely occurs, it can be gestational or non gestational. Gestational choriocarcinoma usually follows a molar pregnancy, normal pregnancy, spontaneous abortion or an ectopic pregnancy unlike the non gestational type in which there is no convincing evidence of pregnancy. Interestingly, choriocarcinoma is a distinctly rare occurrence in an ec- topic gestation. It's incidence is one in 533 of tubal pregnancies and one in 1.6 million normal intra uterine pregnancies $(1,2)$. In fact, only $0.76-4 \%$ of choriocarcinomas has been reported in ectopic location $(3,4)$.

\section{CASE REPORT}

Miss AO, A twelve year old girl was referred to our hospital with a history of amenorrhea of 16 weeks following an unprotected sexual intercourse with a 16 year old male teenager. She had complained of lower abdominal pains of 1 week and dizziness in the duration of 2 days; having just attained menarche and had only menstruated twice prior to her presentation in our hospital. Her urine pregnancy test before presenting at our facility was positive and two attempts were made to evacuate the uterus in different private hospitals. However, pelvic ultrasound was not performed, prior to presentation in our hospital.

On examination in the emergency room, she was pale, her pulse rate was 112 beats per minute and blood pressure was $90 / 60 \mathrm{mmHg}$. The abdomen was full and moved with respiration, there was generalized tenderness and a mass was felt in the right lower half of the abdomen. Further examination of the mass was hampered due to severe abdominal tenderness. Vaginal examination revealed a grossly normal cervix, cervical examination tenderness was positive and pouch of Douglas was full. Culdocentesis yielded altered non clotted blood. 
A provisional diagnosis of rupture ectopic pregnancy was made to rule out perforated uterus following voluntary termination of pregnancy via uterine evacuation. Investigation result includes Packed Cell Volume $22 \%$, Blood Group O positive, Serum electrolyte profile was within normal limit. She had an emergency exploratory laparotomy, and intra operative findings revealed haemoperitoneum of about 500 millitres of fresh and altered non clotted blood, grossly intact fallopian tubes bilaterally, grossly normal left ovary, an enlarged right ovary with multiple cystic appearances and areas of rupture and active bleeding seen. The uterus was normal with no evidence of perforation. Right ovariectomy was performed and post operative recovery was uneventful; she was consulted to abstain from sexual intercourse and the use of contraception. Patient's histopathology report was choriocarcinoma of the ovary. Serum $\beta$ hCG was $>100,000$ IU. Patient and her relatives were counselled on the need to take chemotherapeutic agents and continuous medical follow up care. However, efforts by

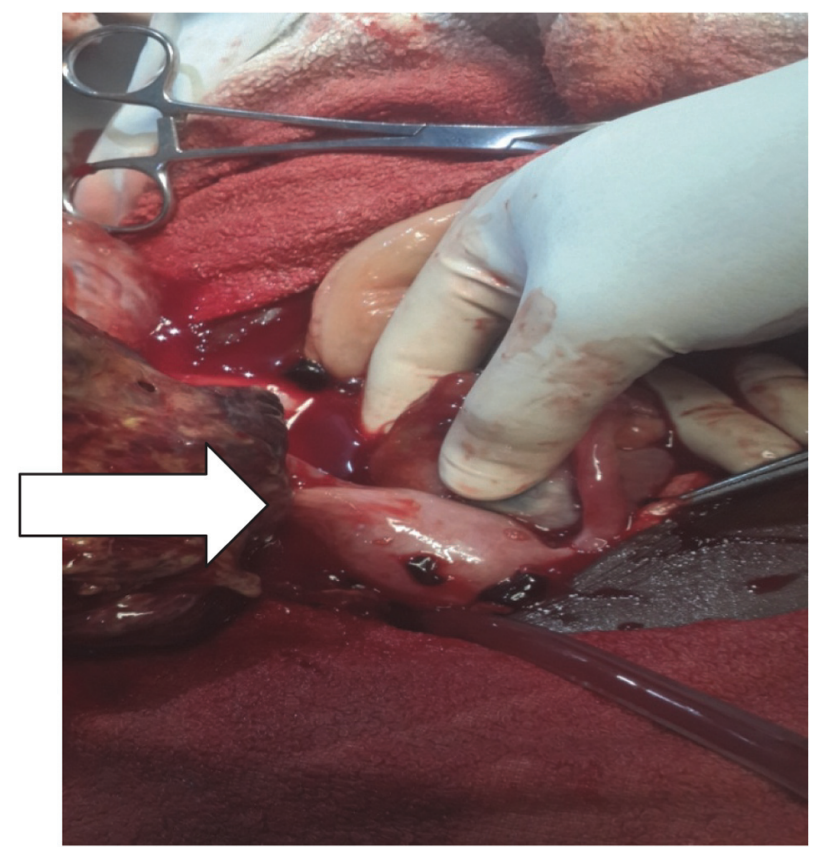

Figure 1a. Arrow showing ovarian mass at surgery

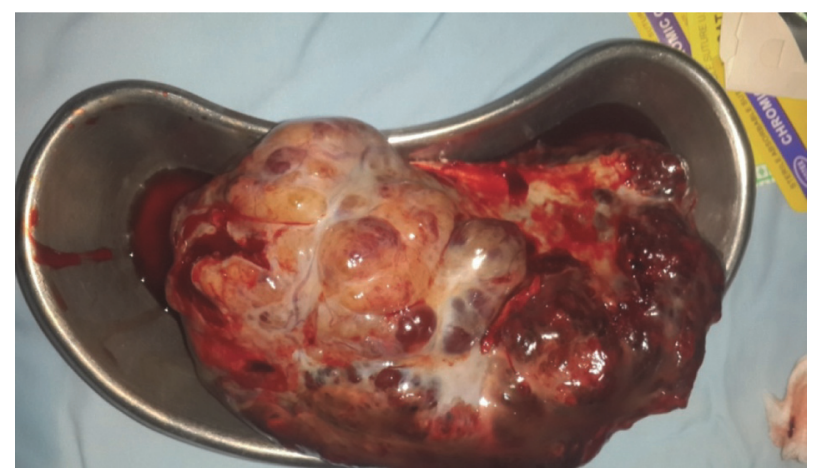

Figure 1b. Specimen in a kidney dish following its removal at surgery the managing team and the social workers to keep patient in the hospital for proper care proved abortive she departed against medical advice (DAMA) due to financial reasons. She represented in our hospital six (6) months later with a history of chronic cough and weight loss suggesting a possible metastasis. Following the initial evaluation and on plan to request for investigations and probably work her up to obtain chemotherapeutic agents. Relatives again declined and subsequently departed against medical advice to seek for care with Traditional Care Givers.

\section{PATHOLOGICAL FINDINGS}

\section{Gross features}

We received $1 \mathrm{~kg}$ formalin fixed lobulated, gray, soft to firm mass of $18 \times 13 \times 10 \mathrm{~cm}$ dimension. Cut surface is hemorrhagic, variegated, partly cystic and partly solid. The cysts contain mucoid secretion (Figure 1a, 1b and 2).

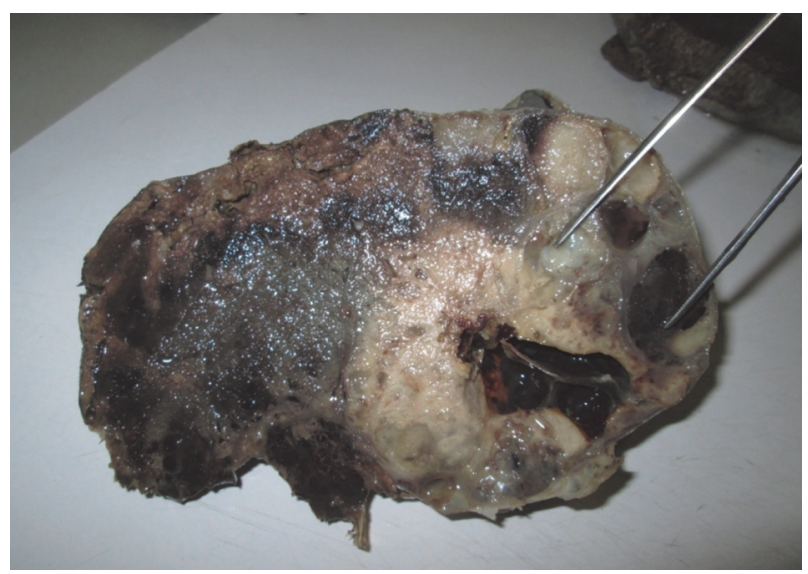

Figure 2. Cut surface of formalin fixed ovarian mass, showing mucoid containing cyst

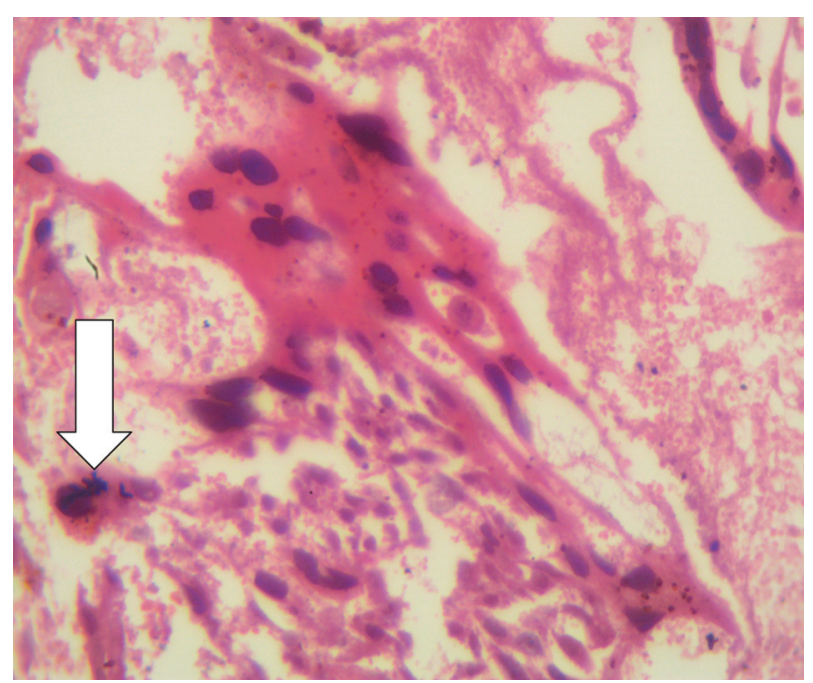

Figure 3. X 100 showing malignant syncytiotrophoblast and cytotrophoblast cells and bizarre mitotic figure (arrow) in pool of hemorrhagic necrosis 


\section{Microscopic features}

The sections show scanty foci of malignant syncytiotrophoblastic and cytotrophoblastic cells and bizarre mitotic figures in pools of extensive hemorrhagic necrosis (Figure 3).

\section{DISCUSSION}

Although, ectopic pregnancy can be diagnosed clinically based on common presenting complaint like amenorrhea associated with abdominal pain, minimal vaginal bleeding and dizziness (5). Choriocarcinoma presenting with the clinical features similar to those of ruptured ectopic pregnancy is an extremely rare event and the diagnosis is usually confirmed histologically (6). Choriocarcinoma is a malignant proliferation of cytotrophoblast and syncytiotrophoblast without the presence of chorionic villi. The usual presentation of choriocarcinoma is in the uterine body, it may stem from chorionic villi following a normal or abnormal gestation. In most instances, choriocarcinoma of the ovary are gestational in origin in contrast to non-gestational choriocarcinoma of the ovary which is an exceedingly rare primary germ cell neoplasm of the ovary with poor prognosis due to its resistance to chemotherapy and metastasis to other organs at the time of diagnosis (7). In the case presented patient had just attained menarche and menstruated only twice before she had a sexual intercourse. However, this is not an enough evidence to classify as gestational choriocarcinoma, because of the inability to differentiate gestational and non gestational choriocarcinoma clinically or histologically. Individuals below 18 years and above 40 years are at greatest risk of developing choriocarcinoma (8). Furthermore, development of the tumour has been shown to vary between 5 weeks and 15 years after gestation or even after menopause (9). Therefore, based on her age and inexperience, it was difficult for her to know the symptoms and signs of early pregnancy, let alone relate her distended abdomen to gestation. When pregnancy was eventually suspected attempt to procure uterine evacuation was made on the assumption of the presence of an intrauterine gestation. This would have been avoided by performing an ultrasound examination.
The peculiarity of our case report is that it is a rare form of an extrauterine malignant trophoblastic disease in a preteenage girl who just attained menarche. Although, it is a treatable disease with good prognosis, the prevailing socioeconomic circumstances like age, poverty, lack of education on the part of the parent(s) and ignorance on reproductive health issues could affect the quality of life of preteenage female children. Furthermore, studies have shown that teenagers become sexually active in early puberty without using any form of contraceptives $(10,11)$.

\section{CONCLUSION}

There is the need to ensure that reproductive health education and awareness is not only limited to our secondary schools. There is an urgent need to expand this frontier of knowledge to the family, primary school teachers and the community at large. The rarity but possibility of both gestational and non gestational choriocarcinoma should be entertained by all healthcare providers. There is a need for synergy between professional health care givers and traditional health practitioners in patient care in order to ensure a proper referral system. Advocacy should be made for youth friendly clinics which will take care of young people including the pre-teenagers, social welfare in our hospital and community must create means of taking care of patients with terminal illness like cancer, so that those with curable diseases can be assisted.

\section{CONFLICT OF INTEREST}

No author has any conflict of interest to declare.

\section{FUNDING}

None

\section{ETHICAL APPROVAL}

Patient's consent was obtained from her mother before they departed against medical advice. Ethical committee approved the work only after demonstrating that the patient was lost to follow up the second time with proposal for the social workers to trace the child and offer treatment at subsidized rate. 


\section{Sažetak}

\section{EKTOPIČNI HORIOKARCINOM KOD PREADOLESCENTA U OGBOMOSO-U, JUGO-ZAPADNA NIGERIJA: PRIKAZ SLUČAJA}

Ogunlaja A. Olumuyiwa, ${ }^{1}$ Ano-Edward H. Gbemi, ${ }^{2}$ Fehintola O. Akintunde, ${ }^{1}$ Alao A. Michael, ${ }^{3}$ Awotunde T. Olufemi, ${ }^{4}$ Ogunlaja P. Idowu, ${ }^{5}$ Aaron Olurotimi, ${ }^{6}$ Idowu Ajibola, ${ }^{7}$ Fehintola O. Funmito, Bojuwoye O. Matthew, ${ }^{8}$ Oladeji A. Sunday, ${ }^{4}$ Lasisi E. Matthew ${ }^{2}$

\footnotetext{
${ }^{1}$ Department of Obstetrics and Gynecology, Bowen University Teaching Hospital, Ogbomoso, Nigeria

${ }^{2}$ Department of Anatomic Pathology, Bowen University Teaching Hospital, Ogbomoso, Nigeria

${ }^{3}$ Department of Pediatrics, Bowen University Teaching Hospital, Ogbomoso, Nigeria

${ }^{4}$ Department of Family Medicine, Bowen University Teaching Hospital, Ogbomoso, Nigeria

${ }^{5}$ Department of Obstetrics and Gynecology, General Hospital, Ilorin, Nigeria

${ }^{6}$ Department of Anesthesia, Bowen University Teaching Hospital, Ogbomoso, Nigeria

${ }^{7}$ Department of Community Medicine,Bowen University Teaching Hospital, Ogbomoso, Nigeria

${ }^{8}$ Department of Internal Medicine, University of Ilorin Teaching Hospital, Ilorin, Nigeria
}

Ektopični horiokarcinom je izuzetno redak tumor. Slučaj koji se razmatra u ovoj studiji odnosi se na 12-godišnju devojčicu, koja je imala bolove u donjem delu abdomena i vrtoglavice, praćenje kratkotrajnom amenorejom, nakon menarhe. Privremeno postavljena dijagnoza, rupture ektopične trudnoće, načinjena je na osnovu kliničke evaluacije. Nakon toga pacijentkinja je hitno podvrgnuta laparoskopskoj operaciji. Histopatološki nalaz potvrdio je dijagnozu horiokarcinoma jajnika. Pacijentkinja je podvrgnuta naknadnom kon-

\section{REFERENCES}

1. Rotas M, Khulpateea N, Binder D. Gestational choriocarcionma arising from a corneal ectopic pregnancy; a case report and review of the literature. Arch Gynecol Obstet. 2007; 276(6): 645-7.

2. Rettenmaler MA, Khan HJ, Epstein HD, Nguyen D, Abaid LH,Goldstein BH. Gestational choriocarcinoma in the fallopian tube. J Obstet Gynaecol. 2013; 33(8): 912-4.

3. Chen MJ, Yang JH, Lin MC, Ho HS, Yang YS. As unusual gestational choriocarcinoma occurring primarily on the surface of a subserous leiomyoma. BJOG. 2004; 111(2): 188-90.

4. Salleh S, Arthur I. Persitent peritoneal trophoblastic implantation following salpingotomy, salpingectomy and methotrexate for ectopic pregnancy. Gynecol Surg. 2005; 2(3): 195-6.

5. Mahmood SA, Thomas JA. Primary ectopic ovarian pregnancy (report of three cases). J Postgrad Med. 1985; 31(4): 219-22.

\section{Correspodence to/ Autor za korespodenciju}

Olumuyiwa A Ogunlaja,

Department of Obstetrics and Gynaecology

Bowen University Teaching Hospital, Ogbomoso, Oyo State. Nigeria.

E-mail: lajamuyiwa@yahoo.com

Telephone: +2348052273290 trolnom praćenju. Ovaj slučaj ukazuje na neophodnost fokusiranja na izazove u vezi sa reproduktivnim sistemom, kao što su rana edukacija o seksualnoj aktivnosti u adolescentnom periodu, kao i na pojavu retkih bolesti kod mladih. Bitno je posvetiti pažnju i na mogućnost pojave negestacionog horiokarcinoma jajnika, koji ima lošiju prognozu.

Ključne reči: ektopični horiokarcinom, preadolescentni period, rupturirana ektopična gestacija, napuštanje zdravstvene ustanove uprkos medicinskim savetima.

6. Boynukalin FK, Erol Z, Aral AL, Bovar IH. Gestational choriocarcinoma arising in a tubal ectopic pregnancy: case report Eur J Gynaecol Oncol. 2011; 32(5): 592-3.

7. Park SH, Park A, Kim JY, Heekwon J, Koh SB. A case of non-gestational choriocarcinoma arising in the ovary of a postmenopausal woman. J Gynaecol Oncol. 2009; 20(3): 192-4.

8. Smith HO, Kohorn E, Cole LA. Choriocarcinoma and gestational trophoblastic disease. Obstet Gynecol Clin North Am. 2005; 32(4): 661-84.

9. Hassada A, Kew FM, Tidy JA, Wells M, Hancook BW. Ectopic gestational trophoblastic disease: a case series review J Reprod Med. 2012; 57(7-8): 297-300.

10. Makiwane, M. The Child Support Grant and teenage childbearing in South Africa. Development Southern Africa. 2010; 27 (2): 195-6.

11. Richter MS, Mlambo GT. Perceptions of rural teenagers on teenage pregnancy. Health SA Gesondheid. 2005; 10(2): $61-9$. 